\title{
The role of animal breeding with special regard to native pigs of food supply and rural development in Laos
}

\author{
Somsy Xayalath ${ }^{1}$ - Eszter Balogh ${ }^{2}-$ József Rátky $^{3}$ \\ ${ }^{1}$ Faculty of Agricultural and Food Sciences and Environmental Protection, University of Debrecen, 4032 Debrecen, Hungary \\ ${ }^{2}$ Research Institute for Animal Breeding, Nutrition and Meat Science, NARIC, 2053 Herceghalom, Hungary \\ ${ }^{3}$ University of Veterinary Medicine, 1078 Budapest, Hungary \\ xayalath.somsy@agr.unideb.hu
}

SUMMARY

\begin{abstract}
The present paper explored the influence of breeding native pigs on livelihood conditions and the contribution of native pigs to the rural development and rural poverty reduction in the rural areas of Lao PDR. Pig production plays an important role in meat supply for both urban and rural areas of Laos. It is clear that most of the pig products in the country come from smallholder pig farms, and more than 90 percent of those products are the native pigs mostly raised by farmers in remote areas. In general, livestock production distributed between 15-18 percent to GDP, while most of animal production still remains as the traditional methods. Rural development is always the first priority of the Laos government since its independence in 1975, however, the poverty rate in rural areas remained high at $23 \%$ in 2018. It might block the development goal of the government which will lead the country out of the least development status by 2020. The food security and malnutrition in the rural or mountainous areas are considered as the majority issue that both government and several international organizations have been thriving hard to overcome, which researchers showed that more than $45 \%$ of children under 5 years of age were stunted, and $28 \%$ of them were underweight. Inspired of more than $50 \%$ of the households in the rural areas of Laos reported they consumed chicken and pork at least one day a week. While native pigs play an important role on meat supply, it also constituted around 9-14\% of annual income of the households in rural areas. Therefore, the increase the production of pigs and poultry is one option to promote the meat supply to households in the rural areas of Laos. This paper will be a pathway to guide and identify for the final decision to what experiment will be implemented on Lao native pig in Laos (2021-2023) to complete the comparative study on reproductive physiology and reproductive management methods of Hungarian and Lao Indigenous pig breed. Which found it still needs further afford to research and improve more about native pig performance for all areas of productive and quality management.
\end{abstract}

Keywords: native pig, food supply, poverty, rural development

\section{INTRODUCTION}

Laos or Lao PDR is a landlocked country located in the Southeast Asian region bordering with five countries, China is in the north, Cambodia in the south, Vietnam in the east, Thailand in the west, and Myanmar is in the north-west. Laos has 236,800 square kilometers with more than $70 \%$ is the mountainous areas. About 6.5 million people (2018) live in its 18 provinces, with more than $68 \%$ of the population still living in rural areas based on agricultural and natural resources for survival (UNDP Lao DPR, 2018). Agriculture plays an important role for national employment, however, it has also been continuously decreasing in comparing to other national economic sectors, from $85 \%$ in 1990 s to $64.3 \%$ in 2018 (National Assembly, 2018). Still high remained at $80 \%$ of population in remote areas depend and agriculture for their livelihood, more than half of households are subsistence farmers with annual income below $\$ 300$ (IFAD, 2019), while the average annual income of people in the cities is $\$ 1,600$. Moreover $50 \%$ of agricultural workforces in all part of agricultural production were women (FAO, 2018).

Rural development is a core target and its' main component of Lao government to reduce poverty at 20\% (Ministry of Planning and Investment, 2016), and to lead the country out of the least-developed status by 2020 (Office of Prime Minister, 2018). However, over the last 40 years, the government of Laos has been striving hard on rural development and poverty reduction, it has still remained at a high level of poverty in the wide nation, $23 \%$ of the population still lives under the poverty line (ADB, 2019). There are four types of native pig breeds in Laos, namely in Lao term as Moo Lard, Moo Chid, Moo Hmong, and Moo Daeng (Keonouchanh et al., 2011), and native production is the most important of all animal husbandry for smallholders, particularly in the rural areas (Phengsavanh, 2010), over $90 \%$ of pig population is native pig breeds (Keonouchanh, 2018), and more than $72 \%$ of them are in the rural areas i.e. north and south parts (Lao Statistics Bureau, 2017). Xayalath and Sacklokham (2010) reported that native pig rearing is already a part of farmers' lives in remote areas of Laos ( $85 \%$ of total " 135 " interviewed households raised at least one native pig). Pigs are not only supply daily food for people, but regarding to traditions of rural people, pigs are common animals which people always use for various traditional ceremonies such as wedding, reverence for spirits, etc.

The aims of this paper is to explore how native pig raising influence to the daily lives of households in rural areas, to find what gap should be improved for Lao native pig breeds especially reproductive performance, and to review what important of native pigs to rural poverty reduction in Lao PDR.

\section{RURAL DEVELOPMENT AND POVERTY REDUCTION IN LAOS}

Laos is a landlocked country with most of its area is mountains which created several troubles for 
development projects. Over $73 \%$ of the country's 5.6 million people, in 2006, lived less than $2 \$$ per day (World Bank, 2006). In Figure 1, showed the different gap of poverty between rural and urban areas of Laos which was still a highly significant difference among them. However, the poverty eradication has been satisfactory so far, and it is decreased year by year such as in $1992-1993$ the poverty rate was $46 \%$, declined to
$23 \%$ in 2015. Over 40 years to now, the rural development issue has always come the first priority of the Lao government, but the poverty still remain high rate, especially in remote areas of north and south parts of the country (AusAID, 2012), around 19\% of total villages " 8,464 " still have no road access i.e. in the rainy season (Lao Statistics Bureau, 2017).

Figure 1: Percentage of poverty ratio in Laos from 1992-2008

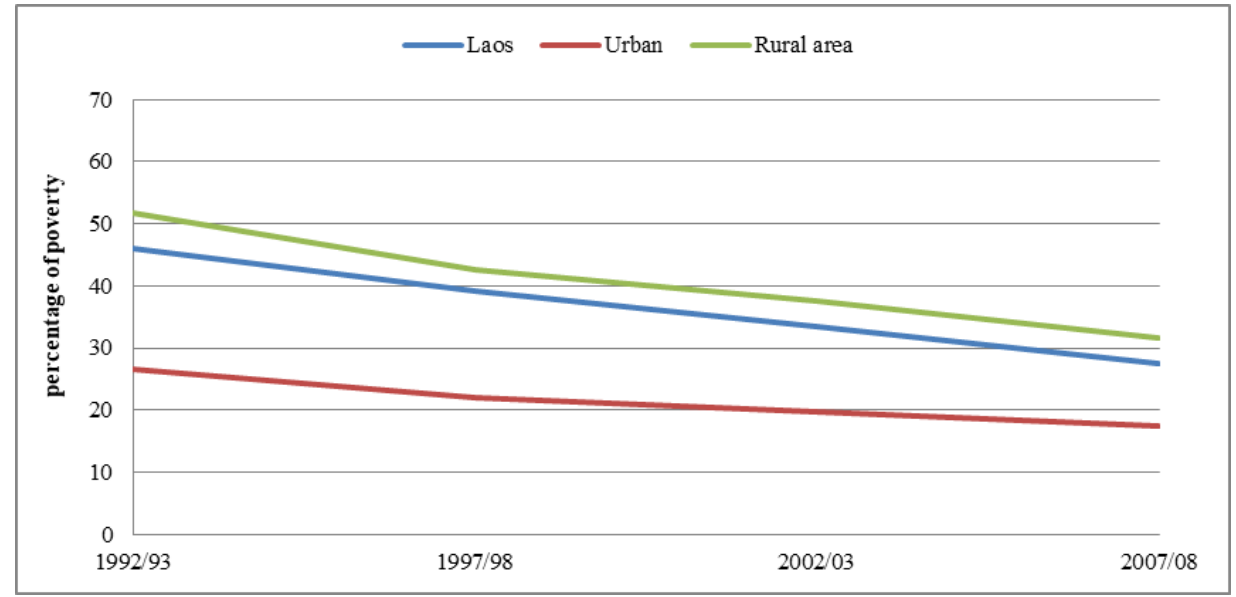

Source: The $7^{\text {th }}$ five-year national social development plan of Laos

\section{LIVESTOCK PRODUCTION IN LAOS}

Animal production contributes an important role to the social-economic plan of Laos, around 16\% of GDP rose from livestock production. Both live animals and products are from small scales traditional production, and about $90 \%$ of households in the country kept one or two species of livestock (Richard, 2007). Large animals i.e. buffalos and cattle are always produced for exporting to the better markets e.g. Vietnam and China, while small livestock such as pig and poultry are produced largely for home/village consumption and local markets (Stur et al., 2002). In South East Asian terms pig is a 'small animal' species. The number of domestic animals in Laos increased significantly by years (Table 1).

Table 1

Statistics of livestock population in Laos from 1975-2015 (thousand heads)

\begin{tabular}{ccccccc}
\hline \multirow{2}{*}{ year } & \multicolumn{7}{c}{ Species } \\
\cline { 2 - 7 } & Buffalo & Cattle & Pig & Goat & Poultry & Fish \\
\hline 1976 & 668 & 326 & 764 & 31 & 4,076 & - \\
1980 & 855 & 445 & 1,111 & 48 & 4,619 & - \\
1985 & 721 & 628 & 1,191 & 81 & 6,471 & - \\
1990 & 1,060 & 851 & 1,436 & 109 & 8,045 & - \\
1995 & 1,191 & 1,146 & 1,580 & 153 & 11,441 & - \\
2000 & 1,007 & 978 & 1,101 & 100 & 12,032 & - \\
2005 & 1,097 & 1,272 & 1,827 & 190 & 19,802 & 72,600 \\
2010 & 1,183 & 1,475 & 2,753 & 366 & 24,078 & 82,100 \\
2011 & 1,196 & 1,538 & 2,650 & 433 & 26,852 & 95,510 \\
2012 & 1,188 & 1,692 & 2,794 & 444 & 28,779 & 101,895 \\
2013 & 1,190 & 1,714 & 2,948 & 470 & 30,727 & 103,896 \\
2014 & 1,153 & 1,766 & 3,122 & 481 & 32,408 & 90,355 \\
2015 & 1,165 & 1,828 & 3,258 & 533 & 34,422 & 95,965 \\
\hline
\end{tabular}


Pig production was the $3^{\text {rd }}$ main supply sources of meat (after fish \& chicken) to serve Lao people (MoAF, $2010)$, in 2018. Laos has the population of pigs around $3,820,000$ heads (MoAF, 2019) with around $90 \%$ of those pigs population is native pig breeds (Keonouchanh, 2018). By 2020 pork production shall be 95,500 tons and by 2025 shall be at least 116,200 tons, which priority to promote native pig rearing for supplying pork to domestic consumption in rural districts of provinces (MoAF, 2015). Native pigs are commonly kept in three production systems i.e. freescavenging (seasonally or year-round), confined in enclosures and penning (Phengsavanh and Stur, 2008).

The main constraints of pig production in Laos are (1) poor management particularly in rural areas (Stur et al., 2002) which based on traditional practice as freerange raising system. Most of farmers always let their pigs roam freely and scavenge in the forest and surrounded areas nearby the village (Keonouchanh et al., 2011). (2) Poor reproductive performance is also the major constraint problem of pig production in smallholder pig farms in Laos i.e. low piglet growth rate (20-50g/day) and high mortality (30-50\%) (Phengsanh et al., 2010; Chittavong et al., 2012). The reasons of high mortality in piglets might link to poor management, inappropriate feeding and caring for sows and piglets of farmers (Xayalath and Sacklokham, 2010). Most farmers do not have any method to control their pig reproductive management, they always let their gilts or sows in free-range and sometimes they do not even know when and which boar mated their sow. $73 \%$ of farmers (149 households) reported they did not know when and where their sows gave birth the piglets (Xayalath et al., 2016). (3) Low input and insufficient feed are other problems of pig raising in small scale pig farms in Laos. Many smallholder farmers do not provide enough feed of both amount and nutrition value for their pigs (Kaensombath et al., 2012). Feed and feeding system for pigs raising in smallholder pig farms in Laos based on the traditional system and depend on available residues from crop production and green vegetable from the forest such as rice bran, broken rice, fresh cassava, maize, brewer grains, taro leaves, other green vegetables (Phengsanh et al., 2010; Chittavong et al., 2012). (4) Outbreak or annual outbreaks of diseases are also major problem for smallholder pig farms in Laos i.e. classical swine fever (CWF) is an epidemic in Laos with several outbreaks reported annually, and it accounted the large number of pig deaths in all pig raising systems (Vongvilath and Blacksell, 1999). (5) Lacking of opportunity to access the markets even local and near city markets is still a serious constraint of pig raising or pig raising promotion of smallholder pig farms in Laos. The important information about the market or consumers' need still not clearly communicated to producers which farmers do not recognize as the weak point of their products (Chadwick et al., 2008).

\section{Food supply security in Laos}

However, the government of Laos has been thieving hard for many decades to fright the hunger for its people i.e. in the rural areas, but the malnutrition is a major challenge in Laos, and it still remains a concreted problem which blocks to overcome the hunger related millennium development goal. In 2012, the prevalence of underweight children remained at $27 \%$, while the sustainable development goals (SDG) indicated at $18 \%$ by 2015 . In addition, $44 \%$ of children less than five years were stunted, the prevalence of stunting, underweight and malnutrition is associated with poverty and geography (WFP, 2013). This is the same as the survey of MoAF in 2012/13 on risk and vulnerability among households in Laos (MoAF, 2013). More than $13 \%$ of living rural households suffering chronic food supply insecurity or two-thirds of households are vulnerable to food supply insecurity due to natural disasters or loss of access to natural resources (Fullbrook, 2010). Based on the survey of FAO in 2011 indicated that overall undernourishment in Laos decreased from $31 \%$ in $1990 / 92$ to $22 \%$ in 2006/08.

The increase of production is still considered as the priority and will continue to play an important role in agriculture development. However, to achieve food supply security, it is necessary to rely on productive diversification apart from the rice (MoAF, 2015). To attain the basic of food security for Lao people, the Ministry of Agriculture and Forestry (MoAF) indicated basic consumption of Lao people per year as appeared in its Agriculture Development Strategy (ADS) from 2011-2020 as described in Table 2, which showed that rice remains the main stable food, and pork consumption is the $3^{\text {rd }}$ of meat supply sources, for food supply security in Laos by 2020.

Table 2

Comparison of food supply security target of Laos (2015-2020)

\begin{tabular}{lcc}
\hline \multirow{2}{*}{ Basic stable food } & Consumption/kg/person/year \\
\cline { 2 - 3 } Rice & 2015 & 2020 \\
Starch & 180 & 167 \\
Fish & 5.3 & 4.9 \\
Chicken & 25.5 & 31 \\
Pork & 9.5 & 11.6 \\
Other meat & 6 & 7.7 \\
Egg & 9 & 11.3 \\
Corn & 3 & 3.4 \\
Vegetables & 1.6 & 1.5 \\
Beans & 37.4 & 44 \\
Root vegetables & 0.6 & 0.7 \\
Fruit & 1.5 & 1.8 \\
Sugar & 6.9 & 8.1 \\
Cooking oil & 1.4 & 1.3 \\
Milk & 14.5 & 25.5 \\
\hline & 1 & 1.1 \\
\hline Total & 303.2 & 320.9 \\
\hline
\end{tabular}

Source: MoAF of Lao. Asian Development Bank 2011-202 
THE IMPACT OF NATIVE PIG PRODUCTION ON THE LIVELIHOOD OF FARMERS IN RURAL AREAS OF LAOS

Native pig is considered as the essential animals and influence to dairy lives of farmers in remote areas of
Laos. With more than $85 \%$ of households in the rural area provinces of Laos owned at least one pig for their households, in average, it contributed annual income to the families between 10-14 percent (Figure 2).

Figure 2: The sharing of annual income from the pig production of rural households in Laos

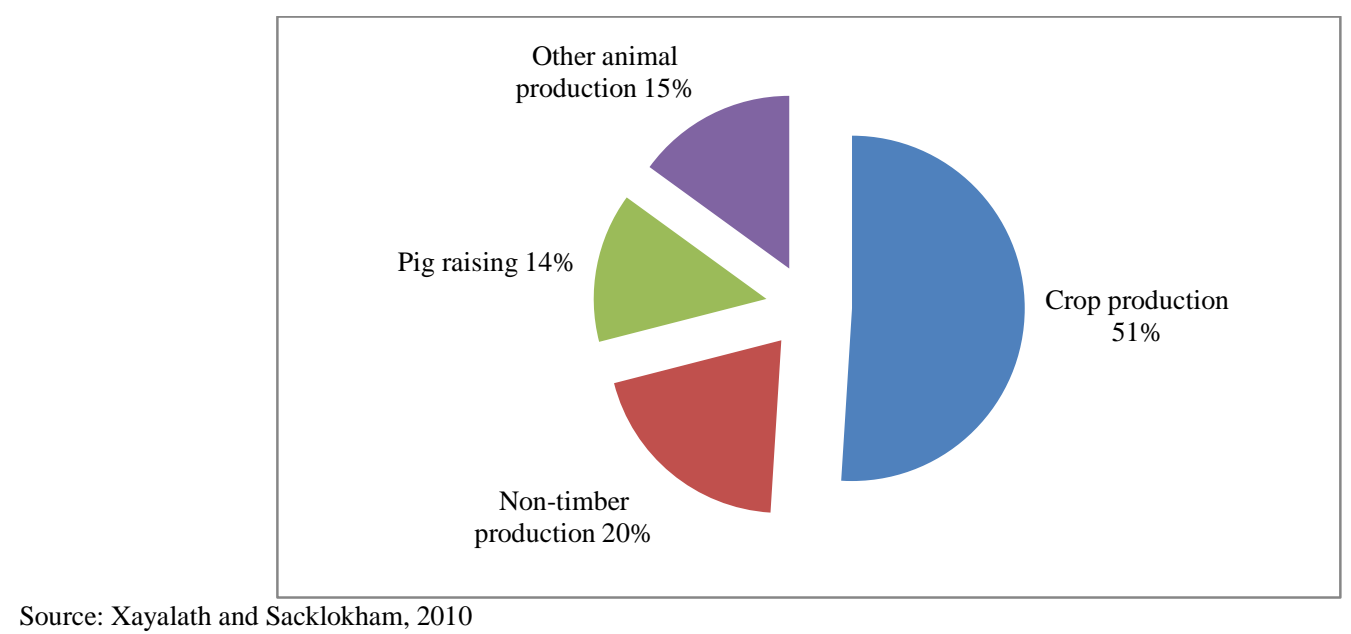

Farmers do not only use their native pigs for their household's consumption, but pigs are also their saving account which can use anytime when family needs money e.g. for their children education, in case of family members' sickness or if households need money to support their new season for crop production (Xayalath and Sacklokham, 2010; Xayalath et al., 2016). It is not clear to determine specific linkages between the development of livestock and improvement in human nutrition. However, improvement in livestock productivity on small farms is only one option to increase the supply of meat for household consumption (FAO, 2014). Small animals i.e. poultry and pigs are considered as the majority of meat supply for households in the rural areas of Laos i.e. 54 percent of households reported consuming poultry and 52 percent reported they consumed pork at least one day a week (MoAF, 2013). Pig fat is still the main fat used for cooking in the remote areas of Laos and the native pigs could provide plenty of fat for this purpose (Phengsavanh and Stur, 2008).

Native pig raising would not only play an important role in food supply security for household for the rural areas residents of Laos, but it is also a good option for farmers to increase income for the households via market niche in the big cities of countries with better external markets i.e. Vietnam, and China who have more pork consumers (Xayalath et al., 2016). Only to achieve this level, farmers need to improve more both production system and quality management to increase more performance and to meet the required market need (Phengvilaysouk et al., 2018). However, the link of critical information between rural household producers and urban consumers should be matched to each other (Chadwick et al., 2008), and it should also be improved more i.e. increase the capacity or increase their supply capacity with the need for the daily market (NAFRI, 2007).

\section{CONCLUSION}

Although, rural development and property reduction is always the first priority policy of Lao government since it had independence in 1975, it still remains in a high ratio of poverty as $23 \%$ in Laos, especially in some rural area provinces are higher than $40 \%$. It might because of most of the country area is mountains which always blocks the process of nations' development targets. Food supply security is another issue which has more challenges and needed more development. As showed in the report of the world food program in 2013, around $27 \%$ of Lao children less than five years of age was underweight, and $44 \%$ of this age group was stunted.

It seems clear that rice is the main stable food, but only rice would not be able to meet or overcome the hunger and malnutrition in rural areas of Laos as indicated in SDG. It is also clear that livestock production plays an important role to the socialeconomic development of Laos, it contributes around $15-20 \%$ in the sharing of GDP. Approximately $90 \%$ of households in the country keep at least one species of animals in their households. Native pigs and poultry are two majority components of meat supply security for households in rural areas of Laos, which approximately $54 \%$ of households consumed poultry and $52 \%$ of those households consumed pork at least once a week. In addition, the native pig is not only the main source of 
meat supply for households, but it is also a saving account for households in rural areas which they can use anytime. Moreover, native pig production always shares annually income for households in remote areas of Laos around 10-15 percent. Native pig might not be only the better option to supply the sustainable meat source to households in the mountainous areas of Laos; it is also the option to increase income for households by increasing the capacity supplying organic quality pork to urban markets or even nearby neighboring countries as Vietnam and China. However, it still needs further afford to research and improve more about native pig performance for all areas of productive and quality management.

\section{REFERENCES}

Asian Development Bank “ADB” (2019): Poverty in Lao PDR. Basic Statistic. Retrieved on October 14, 2019 from https://www.adb.org/countries/lao-pdr/poverty.

AusAID (2012): Australia Laos rural development delivery strategy 2012-16. PP 5-6. Retrieved on October 18, 2019 at https://dfat.gov.au/about-us/publications/Documents/laos-ruraldevelopment-strategy.pdf.

Chittavong, M.-Lindberg, J. E.-Jansson, A. (2012): Feeding regime and management of local Lao pigs in Central Lao PDR. Tropical Animal Health and Production. Volume 45, issue 1, pp 149-155.

Chadwick, K.-Otte, J.-Roland-Holst, D. (2008): Information failure in livestock markets: Evidence from Lao PDR. FAO: online http://www.fao.org/3/a-bp275e.pdf.

FAO (2018): Country and gender assessment of agriculture and the rural sector in Lao People's Democratic Republic, Vientiane, pp 72.

FAO (2011): Country profile for food security in Lao PDR. Retrieved on October 22, 2019 from http://www.fao.org/fileadmin/templates/ess/documents/food_se curity_statistics/country_profiles/eng/LaoPDR_E.pdf.

FAO (2014): Lao census of agriculture 2010/11 analysis of selected themes. pp 81. Retrieved on October 22, 2019 from http://www.fao.org/3/a-at767e.pdf.

Fullbrook, D. (2010): Food as security-LAD. Retrieved on October 22, 2019 from http://lad.nafri.org.la/fulltext/2228-0.pdf.

ILO (2011): Decent Work Country Programme Lao PDR (20112015), page 4. Retrieved on October 17, 2019 from http://www.ilo.org/asia/countries/ lao-peoples-democraticrepublic/WCMS_446091/lang--en/index.htm.

IFAD (2018): Lao People's Democratic Republic, country strategic opportunities programme 2018-2024. Investing in Rural People. Retrieved on October 18, 2019 from https://webapps.ifad.org /members/eb/125/docs/EB-2018-125-R-25.pdf.

IFAD (2019): Investing in rural people in the Lao People's Democracy Republic. Investing in rural people.

Kaensombath, L. (2012): Taro leaf and stylo forage as protein sources for pigs in Laos. Retrieved on October 21, 2019 from https://pub.epsilon.slu.se/9255/1/kaensombath_1_20121122.pdf.

Keonouchanh, S.-Egerszegi, I.-Ratky, J.-Bounthong, B.-Manabe, N.-Brüssow, K. P. (2011): Native pig (Moo Lat) breeds in Lao PDR. Journal-Archives Animal Breeding.

Keonouchanh (2018): KOPIA Project Final Report year 2016-2018. Improved livelihood of farmers by chicken and pig raising in Mork district, Xiengkhuang Province. National Agriculture and Forestry Institute of Laos.

Lao Statistic Bureau (2015): Lao statistics 40 yearbooks. Ministry of planning and investment, Vientiane capital, December 2015.

Lao Statistics Bureau: Statistical Yearbook (2017): Ministry of planning and investment, Vientiane Capital. June, 2018.

MoAF of Laos (2010): Agriculture development strategy 2011-2020.
MoAF (2013): Lao PDR Risk and Vulnerability Survey 2012/13 Analysis Report, Ministry of Agriculture and Forestry. Retrieved on October 23, 2019 from http://www.fao.org/3/a-at537e.pdf.

MoAF of Laos (2015): Agriculture development strategy to 2025 and vision to the year 2030 .

MoAF of Laos (2019): Report of implementing agriculture and forestry in 2018, and development plan for 2019.

Ministry of planning and investment (2011): $7^{\text {th }}$ Five-year national social-economic development plan (2011-2015), Vientiane, October 7, 2011.

Ministry of Planning and Investment (2016): $8^{\text {th }}$ five-year national social-economic development plan (2016-2020), Vientiane, June 2016.

National Assembly of Laos (2018): The article agreement of national assembly of Laos on approval the government's social-economic development implementing plan report for 2018 and approval the social-economic development plan for 2019. No: 0099/NA. Date issued: 21/11/2018.

National Agriculture and Forestry Research Institution (2007): Case study on improving pig production with the need of market retailers in Louangprangbang province's market. Laos.

Phengsavanh, P.-Ogle, B.-Stür, W.-Bodil, E.-Frankow-Lindberg, E. B.-Lindberg, J. E. (2010): Feeding and performance of pigs in smallholder production systems in Northern Lao PDR. Tropical Animal Health and Production, 2010, Volume 42, Number 8, Page 1627.

Phengsavnah, P.-Stur, W. (2008): Farmer-led research in village pig production in Lao PDR. Retrieved on October 23, 2019 from http://lad.nafri.org.la/fulltext/3771-0.pdf.

Phengvilaysouk, A.-Lindberg, J. E.-Sisongkham, V.-Phengsavanh, P.-Jansson, A. (2018): Effects of provision of water on reproductive performance of native Moo Lat pigs in Laos. Tropical Animal Health and Production. Volume 50, py 2018/03/13.

Prime Minister Office of Lao PDR (2018): Lao People's Democratic Republic: Voluntary national review on the implementation of the 2030 agenda for sustainable development goal.

Stur, W.-Gray, D.-Bastin, G. (2002): Review of the livestock sector in Lao people's Democratic Republic. Asian Development Bank. International Livestock Reacher Institute. PP 45. Retrieved October 20, 2019 from https://cgspace.cgiar.org/bitstream/handle/10568/21136/adb_liv estock_review.pdf?sequence $=2$.

United Nations Development Programme \& United Nations Capital Development Fund (UNDP \& UNCDF): Microfinance in rural Lao PDR. A National profile, June 1997.

UNDP (United Nation for Development Programme) Lao DPR (2018): About Lao PDR. Retrieved on October 11, 2019 from https://www.la.undp.org/content/lao_pdr/en/home/countryinfo. html\#Introduction. 
Vongvilath, S.-Blacksell, S. (1999): Classical swine fever in Lao PDR. Australia Center for International Agricultural Research. Pp 122-129. Online http://ageconsearch.umn.edu/record/135364/files/PR094.pdf.

Wilson, R. T. (2007): Status and prospects for livestock production in the Lao People's Democratic Republic. Jo-Tropical Animal Health and Production. DOI: 10.1007/s11250-007-9048-7

World Bank (2006): Lao PDR., Environment monitor report. Vientiane Capital, November 2006.

WFP (World Food Programme) (2013): Food and nutrition security atlas of Lao PDR. Federal for economic cooperation and development. Retrieved on October 22, 2019 from https://documents.wfp.org/stellent/groups/public/documents/en a/wfp260762.pdf.
Xayalath, S.-Sacklokham, S. (2010): Study the impact of villages' Pig Bank implementing in Khua and Samphanh districts, Phongsaly province, Laos. Department of rural economic and food technologies; Faculty of Agriculture; National university of Laos.

Xayalath, S.-Sacklokham, S.-Kaensombath, L. (2016): Study on indigenous pig production system and its market potential for improving livelihood of farmers in Lao Ngam district Saravanh province. Division of post graduated; Faculty of Agriculture; National university of Laos. 